\title{
Legal Liability of Automatic Instrument Results in Environmental Laboratory Analysis
}

\author{
Yusi Luluk Rahmania ${ }^{{ }^{*}}, W$. Widayat ${ }^{1,2}$, Person Pesona Renta ${ }^{3}$ \\ ${ }^{1}$ Center of Research and Service Unit Diponegoro University (CORES DU) \\ ${ }^{2}$ Center of Biomass and Renewable Energy (C-BIORE) \\ ${ }^{3}$ Department of Marine Science, Faculty of Agriculture, University of Bengkulu, Bengkulu, \\ Indonesia
}

\begin{abstract}
The environment is an essential part of human life. Hence, to protect the environment, the application of environmental permits is necessary. Renewable technology has been chosen by several laboratories as an effort to improve services to be fast and precise. This study aims to determine the legal basis and responsibility of errors found in the results of automated instrument analyses in an environmental laboratory. This research was conducted by interviewing Semarang District Court judges, legal experts, environmental experts, and literature study. The data was processed descriptively and analytically using a sociological and juridical approach. Legal liability for errors in the results of environmental laboratories was based on Indonesian Civil Code Article 1234 and Article 1365 , with legal responsibility placed to the consumer, laboratory staff, or laboratory organizer by taking account of the source of the error.
\end{abstract}

Keyword. Legal Liability; Automatic Tools; Environmental Laboratory

\section{Introduction}

The industrial revolution 4.0 that emerged at the beginning of this century encourage all parties to respond to all kinds of changes. The emergence of a digital-based industrial revolution 4.0 supports all lines to make updates. Technology-based hardware is becoming a very lucrative target market. The faster access to information about the struggle of the industrial revolution may have an impact on the rapid development of the industry [1]. With the rapid development of the industry, there must be something to be sacrificed, which is most often than not the environment.

Protecting the environment is the responsibility of every human being. The environment as a fundamental thing in human life must be able to go hand in hand with technological developments without both interfering with each other. For this reason, the government

\footnotetext{
*Corresponding author: yusilrm1994@gmail.com
} 
through Government Regulation Number 27 of 2012 on Environmental Permits mandated every business to obtain an environmental permit. The environmental permit is defined in Article 1 of Government Regulation Number 27 of 2012 on Environmental Permits as "a permit granted to every person who carries out a business and/or activity where environmental impact assessment is necessary, to achieve environmental protection and management as a requirement to obtain a business and/or activity permit." In order to check the environmental impact - as a requirement for obtaining an environmental permit, laboratory testing is necessary. Information about the environmental impact of an industry is very dependent on laboratory results because it can prove whether said industry and/or activity has qualified in the environmental impact assessment. With the growing development of industries, laboratory testing will be in high demand as well - which presented a challenge for laboratory results to be fast and accurate. Many laboratories now use automated instruments as an effort to increase productivity and hence fulfill the need for fast and precise results. The use of automated tools is considered easier, cheaper, and more accurate. Furthermore, automated laboratory equipment can deliver a fast analysis with a very small limit detection. For example, the waste analyzer technology that has a detection limit of ppb units (part per billion). Consequently, laboratories are highly dependent on these automated instruments, thus the awareness of legal aspects regarding errors found in the results should be known by laboratory managers and the public.

\section{Methods}

This study used sociological and juridical methods. Primary data were obtained from interviews, while secondary data were obtained from legislation regulations, books, journals, previous researches, and dictionaries that supported the analysis. Subjects in this study were Semarang District Court judges, environmental laboratory technicians, and legal practitioners. Qualitative data analysis was also used in this study.

\section{Results}

\subsection{Legal Liability Basis on Automatic Instrument Analysis Results in Environmental Laboratories}

Rapid technological development complicates the government to establish rules regarding the latest technology [2]. These circumstances require judges to make decisions based on existing regulations and various other considerations. Errors in the laboratory test results with automated devices have not been specifically regulated in the existing regulations, but in the event of laboratory error, sanctions would still be in effect.

Environmental laboratory consumers (companies or individuals) are protected by Law Number 8 of 1999 on Consumer Protection. In Article 1 Number 1 of Law Number 8 of 1999 on Consumer Protection is stated as follows: "Consumer protection is any effort that guarantees legal certainty to protect consumers." Therefore, environmental laboratory customers acted as consumers while laboratories acted as a provider of goods/services. Consequently, when an unexpected event happened, it was possible for consumers to sue laboratories.

The type of relation between laboratory consumers and laboratory service providers is a legal relation, in other words, it was a relation to performing certain services [3]. An agreement was formed when laboratory consumers on their own will requested for environmental analysis to the laboratory. According to the Civil Code Article 1234, engagement could be in the form of giving, to do, or not to do something. Laboratories took 
part in the engagement role by providing laboratory results (giving), examining samples in accordance with what was agreed upon (doing), and not doing anything (in this case, actions outside the agreed terms). In the case of the laboratory breaching any of the three rule points, the laboratory can be said to be contract negligence.

The customers aimed to obtain laboratory results that correspond to the actual conditions by requesting laboratory analysis. When a sample is accepted by the laboratory, the latter has agreed to carry out the requested examination. Both the customer and the laboratory have the right to determine the initial conditions, one of which is the analysis method used. If both of them have agreed, then an agreement is formed between the laboratory and the customer. In the event that the laboratory produced results that do not correspond to the actual conditions, and are proven to have made a mistake, the laboratory can be called a default.

However, the prosecution could not be easily carried out as risk is a prominent factor. Risk is defined as the obligation to take the loss if there is an event due to an external fault of one of the parties that affect the object stated in the agreement [4]. In the analysis using automated instruments, risk is present, which means errors in the analysis results are plausible. A simple example could be pictured by a vending machine, which often does not give the change back or vice versa. This proves that sometimes problems will still occur in machines despite the optimal maintenance applied. Consequently, as automated instrument analysis exhibits a high risk, the exoneration clause may apply.

Exoneration clause is a clause included in an agreement where one party avoids fulfilling its obligation to pay full or limited compensation, which occurs because of agreement violation or unlawful acts [5]. The exoneration clause must be established by the laboratory to protect its workers. According to Jein Stevany Manumpil, the exoneration clause is valid in an agreement that contains risks [6].

There are other aspects besides negligence on the litigation of laboratory consumers. The laboratory organizer can also be sued for unlawful acts. Based on article 1365 of the Civil Code it states that: "Every act that violates the law, which brings harm to others, obliges those whom because of their mistakes publishes the error to compensate for the loss." In addition to unlawful act lawsuits, the laboratory can also be sued for its negligence. The claim for negligence can be seen in article 1366 of the Civil Code which contains the following: "Everyone is responsible not only for losses caused by their actions but also for losses caused by negligence or carelessness."

\subsection{Legal Liability of Disputes on Automated Instrument Laboratory Results}

Analysis taking place in an environmental laboratory is very complex. Most often, the analysis consists of various stages that depended and/or related to each other. If there is an error at one stage, it can result in an error in the final result. Therefore, the collaboration between consumers, laboratory organizers, and laboratory personnel are needed to produce results that are consistent with the facts on the field. If there are results that are not fitting, the judge must also understand the principle. In contrast to civil cases, generally, laboratory analysis errors caused by automated instruments need to be assessed to determine the guilty party. This is due to the fact that both consumers, laboratory operators, and laboratory management have the risk of making mistakes that could result in errors in automated instrument analysis results [7]. Laboratory analysis result errors can be categorized based on the source of the error as follows: 


\subsubsection{Consumer}

Consumers are those who submit environmental analysis request to the environmental laboratory. Consumers can take part in the errors of the environmental laboratory results. For example, in water analysis, if consumers took the water samples without the right procedure, the results would not correspond with the facts in the field.

Consumer compliance with laboratory instructions (in this case laboratory personnel) can also cause errors. Consumers who were dishonest regarding their data - for example, the source of the sample taken - can also contribute to the errors in the results of environmental laboratory tests. According to Hefni Effendi, water samples that have been taken must be immediately analyzed, however, if not possible, suitable storage treatment should be done [8]. Another example regarding river water sampling, if consumers are dishonest regarding the sampling time, it can also result in errors.

Therefore, judges must be careful to determine the guilty party regarding disputes in automated instrument analysis results. In laboratory analysis, there is a high chance of errors on the part of the consumers. Consequently, lab analysis errors resulting from consumer negligence is not the responsibility of the laboratory, but the responsibility of the consumer.

\subsubsection{Laboratory Staff}

In contrast to other laboratory analysis, the environmental analysis consists of two processes, namely sampling and sample inspection. In the sample examination, there are several laboratory personnel directly involved, including the sample collecting officer, sample examiner officer, and the results recording officer. The sample collecting officer has to carry out sampling in the field. For example, in air quality testing, laboratory personnel are required to take air samples directly at designated locations. This is due to the fact that to analyze the air quality, samples are required to be taken directly at the location. It is also plausible for laboratory personnel to make mistakes in the sampling process, for example, unfit gas analyzer positioning hence the sample taken is not representative enough. Errors in the sampling process will yield laboratory analysis result errors. Besides the sampling officer, the sample examiner is also vulnerable and has the biggest risk of making mistakes. This is due to the fact that the sample examiner conducts each stage of the analysis. It is plausible that the sample examiner, for example, made a mistake in diluting the sample. Not only the sample officers, reports or record taker officers are also vulnerable. Based on interviews with the report officers, they have admitted to making errors in reports, and was later caught at the results verification stage. Liability in the event of a laboratory error due to the negligence of the laboratory staff refers to Article 1367 of the Civil Code, which stated "A person is not only responsible for the loss due to his negligence, but also the loss due to people under his responsibility and/or effects under his supervision". However, liability as previously described does not free the responsibility of the wrongdoer. In criminal cases, errors are categorized as an individual responsibility that cannot be represented, consequently, the judge must be careful in determining the guilty party. If proven guilty, the said party who made a mistake and/or negligence can also be sanctioned according to the applicable laws, moreover, civil servants will be subjected to Government Regulation Number 11 of 2017 . Whereas in the private sector, employees proven to have made a mistake and/or negligence resulting in an error in the laboratory results may be subjected to sanctions per Law No. 13 of 2003 on Labor. 


\subsubsection{Laboratory Management}

Laboratory management is also a plausible contributor to the errors in the laboratory results. Automated instruments require maintenance, calibration, and room conditions that are appropriate to the needs of the instruments. Consequently, if these conditions are not fulfilled, it will affect the analysis results. Therefore, the laboratory must prove that the equipment has been maintained, calibrated, and placed in a suitable room and condition. In the case that the laboratory cannot give any proof, the offense will be handed to the laboratory management. In Article 1366 of the Civil Code, it was stated: "Every act that violates the law and brings harm to others requires the person who caused the loss due to his mistake to compensate for the loss." Hence, based on this regulation, the laboratory must compensate the consumer.

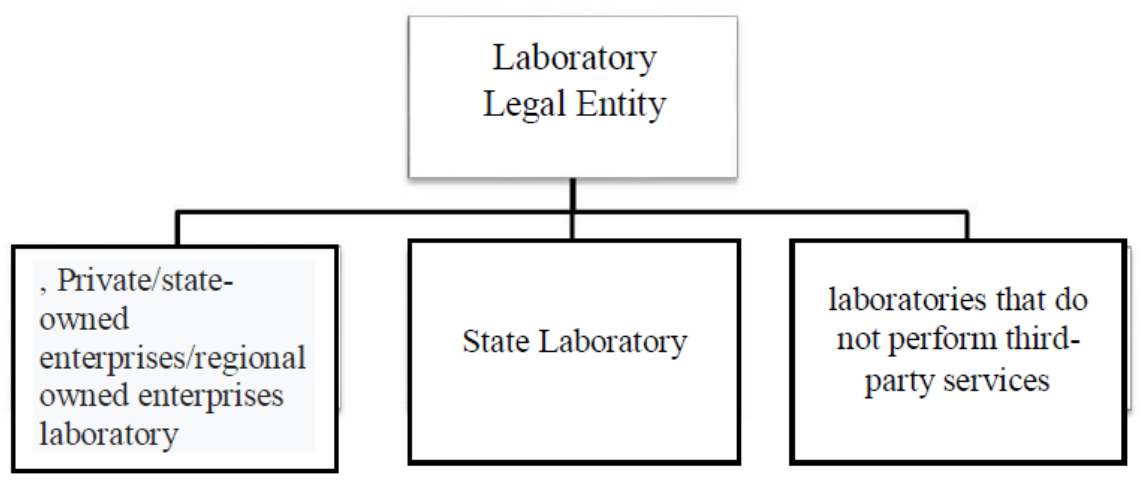

Figure 1. Laboratory Legal Entity

Based on ISO 17025 clause 5.1, laboratories must be a legal entity. The scheme of laboratory legal entity can be seen in Figure 1. Based on ISO 17025, the ownership status or legal entity of a laboratory is divided into three, namely private/state- owned/regionalowned laboratories, laboratories of government institutions, and laboratories that do not provide services to third parties [9]. The Laboratory of State- Owned Enterprises (SOEs) is regulated in Act Number 19 of 2003 on State-Owned Enterprises. In Article 1 of Law Number 19 of 2003 on State-Owned Enterprises, it is explained that SOEs are business entities whose capital investment is wholly or largely owned by the state through direct participation from separate state assets. SOEs can be in the form of limited liability companies or public companies, both of which are legal entities. If an error occurs in the results of laboratory analysis, SOE will be held as the responsible party.

Laboratories can also be in the form of Regional Owned Enterprises (ROE). "ROE in the form of regional enterprises are formed through regional regulations based on Law Number 5 of 1962 on Regional Enterprises. After a regional company becomes a limited liability company, the rules regarding limited liability companies apply to shares owned by the region in whole or in part [10]". If there is a legal dispute related to the error of the ROE's laboratory results, the legal responsibility would be taken by ROE.

A private laboratory must also be of a legal entity. This laboratory can be in the form of a limited company or owned by a foundation. If the laboratory is in the form of a limited company, the legal responsibility lies in the laboratory as a legal entity. Whereas if the laboratory is owned by a foundation, the responsibility lies on the foundation that owns the laboratory.

The second legal responsibility is a government-owned laboratory. In this case, the laboratory can be a laboratory owned by the state government or owned by the regional government. State government-owned laboratories in the event of a dispute are the 
responsibility of the state government or the managing ministry. If the laboratory is owned by the regional government, then the legal responsibility lies with the regional government or the regional head.

Laboratories that do not perform services for third parties are laboratories that carry out tests to support the activities of their parent organizations. This laboratory does not conduct testing for the benefit of other parties, hence, in the event of a dispute, the responsibility lies in the parent organization.

\section{Conclusion}

Fundamentals of legal liability for errors in the results of environmental laboratory analysis with automatic instruments are Article 1234 of the Civil Code and Article 1365. The source of the error should be identified for legal responsibility to be taken into account. If the mistake is due to the consumer then the consumer would be held responsible. Whereas if the error lies in the laboratory officer and/or laboratory organizer, the legal responsibility lies to the owner of the laboratory.

\section{Recommendation}

1. The laboratory must routinely carry out maintenance and calibration, as well as adjusting the laboratory conditions in accordance with what is needed by the instruments. The laboratory must also be careful in formulating the analysis agreement. The application of exoneration clauses is highly recommended for high- risk laboratory analysis. The laboratory should also be careful in accepting samples from consumers to avoid lawsuits due to consumer self-negligence.

2. Laboratory consumers are advised to be careful in choosing laboratories. Accreditation should be considered as it guarantees laboratory quality. Consumers also have to understand the methods used for the analysis to minimize the risk of negligence caused both by the consumer and the laboratory.

3. Laboratory personnel is encouraged to pay closer attention to each stage of the analysis. Officers must record every activity carried out along with the environmental conditions when conducting an analysis or sampling, as the environmental conditions also affect the results of the analysis. Hence in the event of a laboratory dispute, there is enough evidence.

\section{References}

[1] Y. Liao and other; The Impact of The Fourth Industrial Revolution: a Cross- Contry/ Region Comparison; Production; 28; 3 (2018)

[2] R.N.S Koloay; Perkembangan Hukum Indonesia Berkenaan Dengan Teknologi Informasi Dan Komunikasi; Jurnal Hukum Unsrat; 5; 22 (2016)

[3] R Subekti; Aneka Perjanjian; Alumni; Bandung; 69(2006)

[4] R. Subekti; Pokok-Pokok Hukum Perdata Cetakan ke 26; 144 (1994)

[5] M. Darus Badrulzaman; Aneka Hukum Bisnis; Alumni; Bandung; 47 (1994)

[6] J. Stevany Manumpil; 2016; Klausula Eksonerasi Dalam Hukum Perlindungan Konsumen Di Indonesia; Lex Privatum; 4; 3; 36 (2016)

[7] Y. Luluk R. and other; Proving the Accuracy and Legal Liability of Clinical Laboratory Examination Result Using Automatic Tools; Soepra Jurnal Hukum Kesehatan; 5; 2 (2019) 
[8] H. Effendi; Telaah Kualitas Air; Yogyakarta; Penerbit Kanisius (2003)

[9] F. Fatchiyah, Ph.D.; Pedoman Penyesuaian Dengan ISO/IEC17025:2017; diakses dari http://fatchiyah.lecture.ub.ac.id/files/2018/10/Pedomangap_analysis_17025_2017_rev-1_KAN.pdf

[10] Kementerian Hukum dan Hak Asasi Manusia, Artikel Hukum Tata Negara: Kewenangan Kepala Daerah Terhadap Badan Usaha Milik Daerah, diakses dari http://ditjenpp.kemenkumham.go.id/hukum-adm-negara/2943-kewenangan-kepaladaerah-terhadap-badan-usaha-milik-daerah.html 